\title{
SOCIAL COMMUNICATION
}

\section{Правове регулювання діяльності медій в контексті наукового дискурсу}

\author{
Т. О. Приступенко
}

\author{
Інститут журналістики КНУ імені Тараса Шевченка, Київ, Україна \\ Corresponding author. E-mail: prystupenko@gmail.com, https://orcid.org/0000-0001-9546-8228
}

Paper received 13.11.20; Accepted for publication 29.11.20.

\section{https://doi.org/10.31174/SEND-HS2021-249IX44-12}

Анотація. Розглянуто предметну сферу наукового дискурсу щодо правового регулювання діяльності медій. Висвітлено специфіку наукового дискурсу з питань забезпечення права на свободу слова, регулювання роботи журналістів, запобігання проявам порушень свободи слова, необхідності обмеження висвітлення інформації, аналізу зарубіжного досвіду щодо законодавчого забезпечення роботи засобів масової комунікації, правового регулювання електронних засобів масової комунікації. Виявлено тенденції долучення до наукового дискурсу експертної спільноти - юристів-практиків, журналістів, представників медій та громадських організацій.

Ключові слова: медії, діяльність медій, правове регулювання, науковий дискурс, засоби масової комунікаиії.

Вступ. Масові комунікації виступають невід'ємною компонентою сучасного суспільства, а медії - одним 3 найбільш вагомих факторів впливу на формування суспільної свідомості та моделювання поведінки. У цьому контексті правове регулювання роботи медій набуває особливого значення. 3 одного боку, встановлення правової регламентації діяльності засобів масової комунікації (ЗМК) є інструментом захисту громадськості від зловживань 3 боку медій в інформаційній діяльності. 3 іншого - законодавча база функціонування мас-медій, регулюючи характер, зміст та сфери взаємодії держави та ЗМК, стає мірилом демократії в країні. Таким чином, правове регулювання роботи медій не тільки окреслює роль засобів масової комунікації в суспільстві, рамки та межі впливу органів державної влади на ЗМК, але й визначає обов'язки, які беруть на себе медії перед суспільством і державою. Наукові розвідки та дискусії щодо правового регулювання діяльності медій сприяють збалансованості юридичного забезпечення роботи ЗМК з урахуванням інтересів суспільства, держави та медійної спільноти.

Короткий огляд публікацій за темою. Вивчаючи специфіку наукового дискурсу щодо правового регулювання діяльності медій, в першу чергу слід наголосити на існуванні значного наукового доробку, де правовідносини в медійній діяльності розглядаються в контексті інформаційного законодавства. Когортою вітчизняних науковців (Ю.П. Бурило [1], К.А. Ліпкан [25], А.С. Мартюк [12], O.В. Нестеренко [15], B.I. Павликівський [16], O.I. Поклонська [19], Н.А. Савінова [22], В.В. Середюк [24] та ін.) досліджуються питання правового регулювання інформаційних відносин та розповсюдження масової інформації. Медійне право в якості спеціального предмету дослідження розглядається 3.В. Галаджун [3; 4], Н.І. Петровою [17], В.С. Цимбалюком [26] та ін. Окремі юридичні аспекти роботи медій та правові норми журналістики висвітлюються в працях таких авторів, як О.Ю. Бусол [2], Л.І. Данча [5; 6], О.В. Каплій [8; 9], А.В. Кострубіцька [10], Г.М. Красноступ [11], В.Ю. Мільо [13], Л.М. Мудрак [14], Є.О.Письменський [18], Т.І. Приступенко [20], М.Р. Чалабієва [27], В.В. Шаблистий [28].

Важливо відзначити, що діяльність медій є багатоаспектною та охоплює широкий діапазон правовідносин, пов'язаних 3 отриманням інформації, іiї обробкою та поширенням, регулюванням професійної діяльності журналістів, авторським правом тощо. Відповідно, предметна сфера юридичних досліджень щодо роботи засобів масової комунікації характеризується різноманітністю проблематики і потребує подальшого вивчення.

Метою написання статті виступає узагальнення результатів та виявлення векторів вітчизняного наукового дискурсу щодо правового регулювання діяльності медій.

Матеріали та методи. Матеріалами вивчення стали результати досліджень вітчизняних науковців - монографії, навчальні посібники, дисертаційні матеріали, статті у науковій літературі та пресі. Дослідження було проведене із застосуванням загальнонаукових методів пізнання (аналізу, синтезу, класифікації, порівняння, групування та узагальнення).

Результати та їх обговорення. Предметне вивчення правового регулювання діяльності медій носить комплексний характер та передбачає дослідження результатів наукового пошуку, присвячених як розкриттю суто юридичних аспектів діяльності мас-медій, так і висвітленню правових питань у вітчизняному журналістикознавстві.

Враховуючи, що діяльність медій пов'язана з правовідносинами в інформаційній сфері, в першу чергу варто відзначити, що чільне місце у вітчизняному науковому дискурсі щодо правових засад роботи ЗМК посідають питання відносин медій та держави в контексті забезпечення свободи слова та права на інформацію. Зокрема, комплексне дослідження сутності права на інформацію як особистого немайнового права людини в Україні представлено у роботах О.В. Нестеренко [15], А.С. Мартюка [12], В.В. Середюк [24] та ін. Науковий дискурс навколо забезпечення свободи слова передбачає дослідження специфіки правового регулювання роботи журналістів в напрямі запобігання перешкоджанню їх законній професійній діяльності (в тому числі - відповідно до кримінального законодавства України) та представлено в роботах таких авторів, як О.В. Каплій [9], B.I. Павликівський [16], С.О. Письменський [18], В.В.Шаблистий [28] та інші. У попередніх авторських дослідженнях [20] вже наголошувалося на важливості висновків В.В. Шаблистого, що складом злочину може бути лише «перешкоджання законній професійній діяльності журналістів (яка спрямована на реалізацію ними 
своїх повноважень в інформаційній сфері і здійснюється засобами та у порядку, передбаченому законом)» [28, с. 79]. Відповідно «перешкоджання незаконній журналістській діяльності (наприклад, заклики журналіста до захоплення влади або вчинення терористичних актів) складу злочину не утворює» [20, с. 64].

Дослідження фактичних проявів порушень свободи слова та права на інформацію в Україні проводяться міжнародними та національними громадськими організаціями (Freedom House, «Репортери без кордонів», Інститут масової інформації, «Детектор медіа»). Зокрема, Інститутом масової інформації (IMI) у рубриці «Барометр свободи слова» випускаються щомісячні огляди порушень свободи слова, проводяться періодичні моніторинги дотримання професійних стандартів журналістів, аналізується «джинса» (прояви медіа-корупції) та контент медій, вивчаються питання дотримання гендерного балансу в роботі медій.

Одним 3 аспектів правового регулювання дотримання права на свободу слова в діяльності медій є вивчення юридичних аспектів відповідальності ЗМІ та судового захисту в рамках медіа-права (3.В. Галаджун [4]), а також дискурс навколо практики юридичної відповідальності медій за поширення недостовірної інформації та необхідності криміналізації медіа-корупції (О.Ю. Бусол [2]; Н.А. Савінова [22]).

Воєнні дії на Сході України обумовлюють також накладення певних обмежень на висвітлення інформації. Наукові розвідки щодо правових підстав таких обмежень свободи слова та свободи вираження передбачають вивчення особливостей дотримання журналістських стандартів під час висвітлення бойових дій (С.В. Штурхецький [29]), а також забезпечення свободи слова в умовах інформаційної війни та збройного конфлікту (А. Б. Блага, О. А. Мартиненко, Б.С. Мойса, Р.В. Шутов [23]).

Окремий пласт в науковому дискурсі займають праці, присвячені юридичному та ціннісно-етичному регулюванню діяльності журналістів. Зазначене питання перебуває на перетині журналістикозначих та правових досліджень і вивчається в роботах І.С. Бондаренка (2013), О.П. Голуба (2016), В.Ф. Іванова (2006), О.Д. Кузнецової (1998, 2007), Т.О. Приступенко (2020), Я.І. Ширченко (2008) та ін. Доволі прогресивною є позиція О.І. Поклонської, висловлена у дисертаційному дослідженні «Журналіст як суб'єкт інформаційних відносин: конституційно-правовий аспект» (2018). Авторка пропонує «врегулювати питання правового статусу журналіста в одному законі, що дасть змогу уніфікувати вимоги до обов'язків журналістів незалежно від виду 3МI, забезпечить гарантії їх професійної діяльності» [19, с. 34].

Важливою складовою вітчизняного медіаправа $є$ науковий доробок, присвячений правовому регулюванню взаємодії ЗМІ з органами влади (Ю.В. Нестеряк, 2011; Т.М. Слинько, 2012); діяльності ЗМІ як суб'єктів авторського права (О. А. Баранов, 2012; Р.О. Денисова, 2011; I.В. Зайцева-Калаур, 2011; М.Я. Остапчук, 2012; О. I. Харитонова, 2011); правовому регулюванню мовної політики в засобах масової комунікації (О.А. Баранов, 2016; Т.О. Приступенко, 2018, 2019).

Невід'ємною компонентою системи дослідження правового регулювання діяльності медій є наукові розвідки, присвячені аналізу зарубіжного досвіду щодо законодавчого забезпечення роботи ЗМІ. Мова йде про вивчення таких питань, як міжнародно-правові стандарти регулювання в сфері інформаційних відносин, медій та їх застосування у вітчизняному праві (В.В. Середюк, 2009; В.А. Ліпкан, 2012; К.Ю. Примаков, 2016), узагальнення міжнародних принципів законодавчого регулювання медіа (З.О. Кукіна, 2011; Ю.В. Нестеряк, 2015); інституційне забезпечення права на інформацію в законодавстві СС (О.В. Цимбалюк, 2014); напрями адаптації вітчизняного авторського права до законодавства СС (Ю.М. Капіца, 2019); адаптацію вітчизняного законодавства в сфері захисту журналістів та правого регулювання ЗМІ до законодавства ЄС (О.В. Каплій, 2016, 2018); міжнародні стандарти щодо уникнення мови ворожнечі у матеріалах ЗМІ (О.Бондаренко, 2015); парадигми обмеження свободи масової інформації у європейській та американській практиці (В.В. Середюк-Буз, 2011), тощо.

У контексті європейської інтеграції України важливим $€$ науковий доробок, присвячений особливостям державного регулювання медій в Європейському Союзі. Так, в дослідженнях А.В. Кострубіцької [10] проводиться грунтовне вивчення специфіки національних моделей державного регулювання засобів масової комунікації 3 урахуванням форм власності, представлено практичні пропозиції з вдосконалення чинного законодавства України, яке регулює діяльність ЗМК, та приведення його норм до стандартів ЄС.

Розвиток науково-технічного прогресу та цифровизація суспільства обумовили тенденції конвергенції існуючих медіа та появи так званих «нових медій», відмінною рисою яких можна виділити використання «інтернет-технологій, інтерактивність та можливість користувача генерувати власний контент» [13, с. 115].

Актуалізація питання правового регулювання електронних ЗМІ в науковому дискурсі знайшла відображення у дослідженнях щодо становлення та перспектив правового регулювання нових медіа (Ю.П. Бурило [1]; О.В. Каплій [8]; Г.М. Красноступ [11]); досвіду СС в регулюванні діяльності конвергентних медіа (Л.М. Мудрак [14]), проблем правого регулювання ЗМІ в інтернеті (В.Ю. Мільо [13]; А.О. Ярош [30]).

Зокрема, у дисертаційному дослідженні О.В. Каплій «Конституційно-правові засади організації та діяльності засобів масової інформації в Україні» [8] (2014р.) було вперше обгрунтовано необхідність віднесення інтернетЗМІ до засобів масової інформації та відзначено необхідність комплексного міжнародного підходу до вирішення питання правового регулювання діяльності інтернет-медіа через транскордонний характер інтернету.

М.Р. Чалабієва, вивчаючи конституційно-правовий статус електронних засобів масової інформації (2019р.), обгрунтовує належність соціальних мереж до інтернет3МІ та наголошує на особливому значенні нових медіа в «системі організаційно-правових гарантій прав і свобод людини і громадянина» [27, с. 16].

Грунтовний внесок у вивчення та узагальнення вітчизняних правознавчих досліджень та вітчизняного журналістикознавчого дискурсу щодо правового регулювання діяльності мас-медіа було зроблено в роботах Л.І. Данчі [5; 6]. Досліджуючи наукові розробки у сфері правового регулювання медій, автор доходить висновку, що «наявні правознавчі розвідки охоплюють усі ланки мас-медійної діяльності щодо створення, збирання, одержання, зберігання, використання, поширення інформаціï» [5, с. 11], а в журналістикознавстві відбувається 
конвергенція «журналістикознавчих та правових досліджень і поява публікацій, наближених до юридичного дискурсу» [6, с. 109]. Погоджуючись 3 висновками автора, варто наголосити на тенденціях долучення до наукового дискурсу експертної спільноти - як з боку юристівпрактиків, так і з боку медійників.

Необхідність подальшого розвитку правової бази регулювання діяльності медій відповідно до умов сучасності обумовлює розширення дискурсу з суто наукового до науково-експертного, коли до обговорення активно залучаються медійні експерти-практики та громадські організації. Зокрема, протягом останнього року увага науково-експертної медіа-спільноти була прикута до нового Закону «Про медіа» [21], проєкт якого було подано до Верховної Ради України 27.12.2019 р. Незважаючи на численні доопрацювання та внесення правок, журналісти та громадські організації наголошують, що законопроєкт і досі «обмежує свободу слова в Україні» [7].

Висновки. Таким чином, різноманітність правовідносин, які виникають під час роботи засобів масової комунікацій та журналістської діяльності, обумовлюють широку предметну сферу охоплення наукового дискурсу щодо правового регулювання діяльності медій. Дослідження вітчизняних науковців стосуються юридичних аспектів захисту права на свободу слову та права на інформацію, запобігання перешкоджанню законній професійній діяльності журналістів, аналізу зарубіжного досвіду щодо законодавчого забезпечення роботи 3MI; врегулювання питань мовної політики, авторського права та взаємодії медій з органами влади; враховують необхідність більш детального вивчення особливостей державного регулювання медій в СС в контексті євроінтеграційного вектору розвитку України та правового регулювання обмежень висвітлення інформації через воєнні дії на Сході України; охоплюють актуальні завдання здійснення наукових розвідок щодо правового регулювання нових медій та масових соціальних комунікації в мережі інтернет.

Як і суспільне життя, науковий дискурс трансформується та набуває сучасних рис. Зокрема, відбувається конвергенція правознавчих розвідок із результатами журналістикознавчих досліджень, коли вивчення правового регулювання діяльності медій набуває більш прикладного характеру та враховує соціальні аспекти (свобода слова, суспільні цінності тощо). Особливо слід наголосити на активізації процесів залучення експертної медіа-спільноти до обговорення правових питань роботи засобів масової комунікації.

\section{ЛІТЕРАТУРА}

1. Бурило Ю.П. Господарсько-правові засади інформаційної діяльності : монографія. К. : НДІ приват. права і підприємництва ім. акад. Ф. Г. Бурчака НАПрН України, 2013. 343 с.

2. Бусол О.Ю. Медіа-корупція в Україні: проблема криміналізації // Інформація і право, 2016. № 1. С. 102-109.

3. Галаджун 3.В. Правові норми журналістики України: навч. посіб. Львів: Сполом, 2016. 190 с.

4. Галаджун 3.В. Межі права на свободу слова: юридичний аспект соціальної відповідальності засобів масової інформації // Наукові записки Інституту журналістики: науковий збірник / за ред. В.В. Різуна. К. : КНУ імені Тараса Шевченка, 2010. T. 41. С. $157-164$.

5. Данча Л.І. Правове регулювання діяльності мас-медіа у світлі вітчизняних правознавчих досліджень 1990-2010-х рр. // Інформаційне суспільство, 2016. Вип. 24. С. 6-13.

6. Данча Л.І. Проблема правового регулювання діяльності масмедіа у вітчизняному журналістикознавчому дискурсі 1990 2010-х pp. // Держава та регіони. Серія : Соціальні комунікаціï, 2016. № 4. С. 106-111.

7. Журналісти та громадські організації просять Верховну Раду не розглядати законопроєкт про медіа. ГО «Детектор медіа». 14.12.2020.

https://detector.media/community/article/183330/2020-12-14zhurnalisty-ta-gromadski-organizatsii-prosyat-verkhovnu-radune-rozglyadaty-zakonoproiekt-pro-media-zvernennya/

8. Каплій О.В. Конституційно-правові засади організації та діяльності засобів масової інформації в Україні. :. дис. ... канд. юрид. наук : 12.00.02; кер. роботи Б. А. Пережняк; Нац. ун.-т Одеська юридична академія». Одеса, 2014. 196 с.

9. Каплій О.В. Посилення кримінальної відповідальності за вчинення злочинів проти журналістів у світлі адаптації законодавства України про діяльність ЗМІ до європейських стандартів // Новітні кримінально-правові дослідження-2016 : зб. наук. пр. / відп. ред. О. В. Козаченко. Миколаїв : Іліон, 2016. C. 74-78.

10. Кострубіцька А.В. Особливості державного регулювання діяльності засобів масової комунікації у Європейському Союзі : дис. ... канд. наук 3 держ. упр. : 25.00 .02 «Механізми державного управління»; Нац. акад. держ. упр. при Президентові України. Київ, 2017. 203 с.

11. Красноступ Г.М. Нові медіа: становлення та перспективи правового регулювання//Інформація і право, 2012.№2.С.2932.

12. Мартюк А.С. Право на інформацію як особисте немайнове право фізичних осіб // Південноукраїнський правничий часопис, 2014. № 3. С. 98-100.

13. Мільо В.Ю. Проблеми правового регулювання діяльності «нових медіа» // Інформаційна безпека людини, суспільства, держави, 2017. № 1. С. 114-123

14. Мудрак Л.М. Конвергентні медіа як об'єкт державного регулювання: досвід СС//Державне управління: теорія та практика, 2013. № 1: http://nbuv.gov.ua/UJRN/Dutp_2013_1_19

15. Нестеренко О.В. Конституційне право на доступ до інформації: сутність, зміст та обсяг // Юридична Україна, 2008. № 3. C. 26-32.

16. Павликівський В.І. Світові стандарти свободи слова та їх значення для вдосконалення кримінального законодавства України // Вісник Асоціації кримінального права України, 2014. №2 (3). С. 197-207.

17. Петрова Н.І. Медіа-право / Н.І. Петрова, В. Якубенко. К.: Київська типографія, 2007. 276 с.

18. Письменський Є.О. Злочини у сфері професійної діяльності журналістів у контексті забезпечення потреб українського суспільства на сучасному етапі його розвитку // Вісник Кримінологічної асоціації України, 2016. №1 (12). С. 90-103.

19. Поклонська O.I. Журналіст як суб'єкт інформаційних відносин: конституційно-правовий аспект [Текст] : дис. ... канд. юрид. наук : 12.00.02. наук. кер. роботи Т. М. Слінько ; Нац. юрид. ун-т ім. Ярослава Мудрого. Харків : б. в., 2018. 208 с.

20. Приступенко T.I. Права та свободи журналістів у контексті кримінального кодексу України // Образ, 2018. Вип. 3 (29). C. $60-66$.

21. Про медіа. Проект Закону № 2693-д від 02.07.2020 (у доопрацьованій редакції). http://w1.c1.rada.gov.ua/pls/zweb2/webproc4_1?pf3511=69353

22. Савінова Н.А. Кримінально-правова політика забезпечення інформаційного суспільства в Україні : дис. на здобуття наук степеня д-ра юрид. наук : спец. 12.00.08. «Кримінальне право та кримінологія; кримінально-виконавче право». Львів, 2013. 510c.

23. Свобода слова в умовах інформаційної війни та збройного конфлікту / А.Б. Блага, О.А. Мартиненко, Б.С. Мойса, Р.В. Шутов; за заг. ред. О.А. Мартиненка/ Українська Гельсінська спілка з прав людини. К., 2017. 85 с. 
24. Середюк В.В. Свобода масової інформації: конституційноправовий аспект : дис. ... на здобуття наук. ступеняканд. юрид. наук : 12.00.02. Харків, 2010. 200 c.

25. Систематизація інформаційного законодавства України [Монографія] / В.А Ліпкан, В.А. Залізняк / За заг. ред. В.А. Ліпкана. К. : ФОП О.С. Ліпкан, 2012. 332 с.

26. Цимбалюк В.С. Мас-медіа право в інформаційному суспільстві // Інформація і право, 2011. № 1. С. 30-33.

27. Чалабієва М.Р. Конституційно-правовий статус електронних засобів масової інформації. [Текст]: дис. ...канд. юрид. наук: 12.00.02. Харків. нац. ун-т ім. В.Н.Каразіна. Харків, 2019.206с.
28. Шаблистий В.В. Законна професійна діяльність журналіста як «новий об'єкт кримінальноправової охорони» // Вісник Кримінологічної асоціації України. 2015. № 2 (13). С. 78-84.

29. Штурхецький С.В. Особливості дотримання журналістських стандартів під час висвітлення бойових дій // Інформаційне суспільство, 2016. № 23. С. 25-30.

30. Ярош А.О. Засоби масової інформації в інтернеті: проблеми правового регулювання // Інтеграція юридичної науки i практики як основа сталого розвитку правової системи : матер. міжнар. наук.-практ. конф., 8-9 листопада 2018 р. Дніпpo, 2018. C. $155-158$.

\section{REFERENCES}

1. Burylo Yu.P. Economic and legal principles of information activity: a monograph. K.: Private Research Institute. law and entrepreneurship. acad. F.H.Burchaka NAPrN of Ukraine, 2013.343p.

2. Busol O.Yu. Media corruption in Ukraine: the problem of criminalization // Information and Law, 2016. Is. 1. P. 102-109.

3. Haladzhun Z.V. Legal norms of journalism of Ukraine: textbook. way. Lviv: Spolom, 2016. 190 p.

4. Haladzhun Z.V. Limits of the right to freedom of speech: the legal aspect of social responsibility of the media // Scientific notes of the Institute of Journalism: a scientific collection / ed. V.V. Rizuna. K.: Taras Shevchenko National University, 2010. T. 41. S. 157-164.

5. Dancha L.I. Legal regulation of mass media activity in the light of domestic legal research of 1990-2010 // Information society, 2016. Is. 24. pp. 6-13.

6. Dancha L.I. The problem of legal regulation of mass media activity in the domestic journalistic discourse of 1990-2010 // State and regions. Series: Social Communications, 2016. Is. 4. P. 106-111.

7. Journalists and public organizations ask the Verkhovna Rada not to consider the media bill. NGO «Media Detector». 12.14.2020 https://detector.media/community/article/183330/2020-12-14zhurnalisty-ta-gromadski-organizatsii-prosyat-verkhovnu-radune-rozglyadaty-zakonoproiekt-pro-media-zvernennya/

8. Kaplii O.V. Constitutional and legal principles of organization and activity of mass media in Ukraine: dis. ... cand. legal sciences: 12.00.02; ker. works by B.A. Perezhnyak; Nat. University of Odessa Law Academy. Odessa, 2014. 196 p.

9. Kaplii O.V. Strengthening criminal liability for crimes against journalists in light of the adaptation of Ukrainian legislation on the media to European standards // Latest criminal law research2016: collection. Science. etc. / resp. ed. O.V. Kozachenko. Mykolaiv: Ilion, 2016. P. 74-78.

10. Kostrubitska A.V. Features of state regulation of the media in the European Union: dis. ... cand. Sciences of the state control: 25.00.02 «Mechanisms of public administration»; Nat. acad. holding ex. under the President of Ukraine. Kyiv, 2017. 203 p.

11. Krasnostup H.M. New media: formation and prospects of legal regulation // Information and law, 2012. Is. 2. P. 29-32.

12. Martiuk A.S. The right to information as a personal non-property right of individuals // South Ukrainian Law Journal, 2014. Is. 3. P. 98-100.

13. Milo V.Iu. Problems of legal regulation of the activities of «new media» // Information security of man, society, state, 2017. Is.1. P. 114-123

14. Mudrak L.M. Converged media as an object of state regulation: the experience of the EU // Public administration: theory and practice, 2013. Is. 1: http://nbuv.gov.ua/UJRN/Dutp_2013_1_19

15. Nesterenko O.V. Constitutional right to access to information: essence, content and scope // Legal Ukraine, 2008. Is. 3. P.26-32.

16. Pavlykivskyi V.I. World standards of freedom of speech and their significance for the improvement of criminal legislation of Ukraine // Bulletin of the Association of Criminal Law of Ukraine, 2014. Is. 2 (3). P. 197-207.

17. Petrova N.I. Media law / N.I. Petrova, V. Yakubenko. K .: Kyiv Printing House, 2007. $276 \mathrm{p}$.

18. Pysmenskyi Ye.O. Crimes in the field of professional activity of journalists in the context of meeting the needs of Ukrainian society at the present stage of its development // Bulletin of the Criminological Association of Ukraine, 2016.Is.1(12).Pp.90-103.

19. Poklonskaya OI Journalist as a subject of information relations: constitutional and legal aspect [Text]: dis. ... cand. legal sciences: 12.00.02. ker. works by T.M. Slinko; National law University Yaroslava Mudroho. Kharkiv: b. v., 2018. 208 p.

20. Prystupenko T.I. Rights and freedoms of journalists in the context of the Criminal Code of Ukraine // Obraz, 2018. Is. 3 (29). P. 60-66.

21. About the media. Draft Law № 2693-d dated 02.07.2020 (as amended)

http://w1.c1.rada.gov.ua/pls/zweb2/webproc4_1?pf3511=69353

22. Savinova N.A. Criminal-legal policy of providing information society in Ukraine: dis. for the degree of Dr. legal sciences: 12.00.08. "Criminal law and criminology; criminal executive law». Lviv, 2013. 510p.

23. Freedom of speech in the conditions of information war and armed conflict / A.B. Blaha, O.A. Martynenko, B.S. Moisa, R.V. Shutov; za zah. red. O.A. Martynenka / Ukrainian Helsinki Human Rights Union. K., 2017. 85 p.

24. Serediuk V.V. Freedom of mass information: constitutional and legal aspect: dis. ... cand. legal sciences : 12.00.02. Kharkiv, 2010. $200 \mathrm{p}$.

25. Systematization of information legislation of Ukraine: [Monograph] / V.A Lipkan, V. A. Zalizniak / For the general. ed. V.A. Lipkana. K.: FOP O.S. Lipkan, 2012. 332 p.

26. Tsymbaliuk V.S. Mass media law in the information society // Information and Law, 2011. Is. 1. P. 30-33.

27. Chalabiieva M.R. Constitutional and legal status of electronic media. [Text]: dis. ... cand. legal sciences: 12.00.02. Kharkiv. nat. Univ. V. N. Karazina. Kharkiv, 2019. 206 p.

28. Shablystyi V.V. Legal professional activity of a journalist as a "new object of criminal law protection" // Bulletin of the Criminological Association of Ukraine. 2015. № 2 (13). Is. 78-84.

29. Shturkhetskyi S.V. Peculiarities of observance of journalistic standards during the coverage of hostilities // Information Society, 2016. Is. 23. P. 25-30.

30. Yarosh A.O. Mass media on the Internet: problems of legal regulation//Integration of legal science and practice as a basis for sustainable development of the legal system: mater. international scientific-practical Conf., November 8-9, 2018. Dnipro, 2018. P. $155-158$.

\section{Legal regulation of media activity in the context of scientific discourse}

\section{T. O. Prystupenko}

Abstract. The subject area of scientific discourse on the legal regulation of media activities is considered. The specifics of the scientific discourse on ensuring the right to freedom of speech, regulating the work of journalists, preventing violations of freedom of speech, the need to limit the coverage of information, analysis of foreign experience in legislative support of the media, legal regulation of electronic media. The tendencies of involvement of the expert community in the scientific discourse - lawyers-practitioners, journalists, representatives of the media and public organizations - are revealed.

Keywords: media, media activity, legal regulation, scientific discourse, mass media. 